\title{
Effect of Gamma Irradiation Doses on Some Chemical Characteristics of Cotton Seed Oil
}

\author{
O. I. Saleh
}

National Products Research Dept., National Centre for Radiation Research and Technology (NCRRT), P. O. Box 29 Nasr City, Egypt.

\begin{abstract}
COTTON SEEDS c.v. Giza 85 (Gossypium hirsutum L.) were exposed to gamma irradiation doses of $0.5,1.0$ and $1.5 \mathrm{kGy}$ to improve some chemical characteristics of cotton seed oil i.e. saturated and unsaturated fatty acids, gossypol and $\beta$-sitosterol that were bound oil. The presented study showed that, the saturated fatty acids; lauric, palmitic and stearic increased when the cotton seeds were exposed to gamma irradiation doses of 0.5 up to $1.5 \mathrm{kGy}$, On the other hand, arachidic acid content decreased in all the irradiated treatments compared with untreated cotton seed. The unsaturated fatty acid oleic was increased in irradiated cotton seed samples compared with untreated one, while linoleic, the major unsaturated fatty acid decreased in irradiated cotton seed oil than untreated seeds. Gossypol and $\beta$-sitosterol, bound oil, in irradiated cotton seeds increased gradually with gamma irradiated doses compared with untreated control samples.

Keywords: Cotton seed, oil, fatty acids, gossypol, $\beta$-sitosterol
\end{abstract}

Gamma rays belong to ionizing radiation and interact with atoms or molecules to produce free radicals in cells. These radicals have been reported to affect the morphology, anatomy, biochemistry and physiology of plants and can cause damage or modify the plant cell components depending on the irradiation level. These effects include various changes e.g., dilation of thylakoid membranes, alteration in photosynthesis and modulation of antioxidative system (Wi et al., 2005).

Oil of cotton seed has long been considered to be a good vegetable oil for frying but their use was limited as the oxidative stability of cotton seed oil can be lower than other vegetable oils. This is because of its high content of linoleic acid (18:2). To improve the oil stability, cotton seed can be partially hydrogenated which reduces the level of linoleic acid C18:2 (Sacks and Katan, 2002). In addition, the presence of high level content of saturated fatty acid, palmitic $(16: 0)$, in cotton seed oil ( $27 \%)$ contribute functionality in food systems, and 
they also contribute negatively to serum cholesterol profiles (Zock et al., 1994). Also, cotton seed oil retained the highest frying period and long storing time because of its high content of natural antioxidants, namely tocopherols and vitamin E (Srinivasan, 2004). Antioxidants present in cotton seed oil work against the free radicals that cause cell damage aging (Sekhar and Bhaskara, 2011). Cotton and related species contain gossypol, a polyphenolic compound, which act as an integral part of the cotton plant's self-defence system against insect pests and possibly some diseases (Jodi and Gabriela, 2008). Free gossypol is an anti-nutritional factor that limits the use of cotton seed and its products (Hron et al., 1987). Also it is harmful as it blocks spermatogenesis and reduces sperm motility (Sharma et al., 1999). The toxic effect of gossypol can be used against the cancerous cells. It has been found to have antiproliferative activity on tumour cells and is thought to be a potential anticancer drug (Wang et al., 2000), antimalarial drug and potential drug for human immunodeficiency virus (HIV) infection (Luna et al., 2004). Part of gossypol tends to react with many natural substances in cotton seed and forms the bound gossypol which is nonharmful. $\beta$-sitosterol, a known plant sterol, has been reported to be abundant in oils of wheat germ, cotton seed, corn, and soybean (Chen, 1991). The structures of $\beta$-sitosterol and cholesterol are quite similar, so it is reasonable that $\beta$ sitosterol can inhibit the absorbance of cholesterol in the plasma (Mac-Latchy et al., 1995) and in the body (Tatu et al., 2002). $\beta$-sitosterol is a factor used to form the lympho cells and natural killer cells in the immunity process circulation (Bouic et al., 1996). Also, it reduces prostate cancer and coloncancer cell growth (Awad and Fink, 2000). In addition, $\beta$-sitosterol can improve liver function activity (Zak et al., 2005).

The aim of the present work is to study the effect of $\gamma$-irradiation on cotton seeds with respect to its fatty acids; gossypol and $\beta$-sitosterol bound oil contents.

\section{Material and Methods}

\section{Cotton seeds}

Gossypium hirsutum L. cv. Giza 85 obtained from Beni sweif governorate exposed to $\gamma$-rays doses of $0.5,1$, and $1.5 \mathrm{kGy}$. Irradiation was done by a ${ }^{60} \mathrm{Co}$ Hendy Cell Research, NCRRT, Cairo, Egypt at a dose rate of $3.61 \mathrm{kGy} / \mathrm{h}$.

Egypt. J. Rad. Sci. Applic., Vol. 24, No. 1 (2011) 


\section{Lipid extraction}

Lipid extraction from samples was conducted according to the method of A.O.A.C. (2000), using chloroform methanol $(2: 1 \mathrm{v} / \mathrm{v})$. The associated nonlipids were removed by washing lipid extract three times with $\mathrm{CH}_{3} \mathrm{OH}: \mathrm{H}_{2} \mathrm{O}$ $(1: 1 \mathrm{v} / \mathrm{v})$. The lipids, chloroform layer, were dried over anhydrous sodium sulfate, and the solvent was evaporated by heating at $40{ }^{\circ} \mathrm{C}$ under vacuum.

\section{Separation of fatty acids and $\beta$-sitosterol.}

Lipid samples were saponified, overnight, with alcoholic $\mathrm{KOH}(20 \%)$ at room temperature:

i. Separation of $\boldsymbol{\beta}$-sitosterol: The unsaponified fraction, containing $\beta$ sitosterol, was extracted with $4 \times 10 \mathrm{~mL}$ petroleum ether and all the extracts were later combined. The extract was washed with $0.5 \mathrm{~N} \mathrm{NaOH}$ and repeatedly with distilled water until neutral. Traces of moisture were removed by the addition of sufficient amount of anhydrous sodium sulphate. Finally, the extract was evaporated to remove the petroleum ether and redissolved in absolute ethanol.

ii. Separation of fatty acids: The fatty acids were freed from the saponified fraction by acidification with hydrochloric acid $(\mathrm{N})$, followed by extraction with ether. The ether extract was washed three times with distilled water, then dried over anhydrous sodium sulphate, and filtered off (Vogel, 1975).

\section{Preparation of diazomethane}

Diazomethane was prepared from methylamine hydrochloride, Vogel (1975).

\section{Methylation of fatty acids with diazomethane}

Fatty acids liberated from lipid samples and standard fatty acids samples were dissolved in $1 \mathrm{ml}$ anhydrous methanol and the ethereal solution of diazomethane was added in a small portion until the mixture acquired a pale yellow colour and gas evolution ceased. The reaction mixture was left for $10 \mathrm{~min}$ and ether was evaporated under nitrogen stream at room temperature. 2 drops of redistilled chloroform solution was added to dissolve the fatty acid methyl esters and $1 \mu 1$ of this solution was injected into the gas chromatograph instrument.

Egypt. J. Rad. Sci. Applic., Vol. 24, No. 1 (2011) 


\section{Sources of standard fatty acids}

Standard fatty acids (12:0, 14:0, 16:0, 18:0, 18:1, 18:2 and 20:0) with a stated purity of $99 \%$ by Gas Liquid Chromatography (GLC) was purchased from Nu-check Prop. The purity of each fatty acid methyl ester was checked by GLC and gave one peak.

Identification and determination of fatty acids by gas liquid chromatography (GLC)

Fatty acids content of the irradiated cotton seeds were determined at Faculty of Agriculture Research Park (FARP), Faculty of Agriculture, Cairo University according to Farag et al. (1981). Samples were analyzed by GLC (Pye Unicam Series 304), equipped with a flame detector, as follows: glass column (1.5m x 4mm) packed with Diatomite (100-120 mesh) and coated with $10 \%$ polyethylene glycol adipate (PEGA). The column oven temperature rose from $70^{\circ} \mathrm{C}-190^{\circ} \mathrm{C}$ with $8^{\circ} \mathrm{C} / \mathrm{min}$, then isothermally at $190^{\circ} \mathrm{C}$ for $25 \mathrm{~min}$ with nitrogenflow of $30 \mathrm{ml} / \mathrm{min}$.

\section{Determination of $\beta$-sitosterol and gossypol}

$\beta$-sitosterol was analyzed at Faculty of Agriculture Research Park (FARP), Cairo University by Hewlett Packard, HP 1090 High Performance Liquid Chromatography (HPLC) according to Yi and Xiao (2009) using Waters 600 HPLC equipment combined with UV detector at UV 210nm. Symmetry C18 Column $(5 \mu \mathrm{m}, 3.9 \times 150 \mathrm{~mm})$. Column temperature was $30^{\circ} \mathrm{C}$ Mobile phase: $\mathrm{MeOH}$ (HPLC grade). The flow rate was $1.0 \mathrm{ml} / \mathrm{min}$. Sample Loading was $30 \mu 1$.

Gossypol Samples were prepared according to Wang et al. (1985). The dried powdered cotton seed samples (about $0 \times 1 \mathrm{~g}$ ) were macerated with acetone for $16 \mathrm{~h}$, then filtered through $0 \times 45 \mathrm{~mm}$ micro-filter membrane and the residue washed. The extract was evaporated to dryness under vacuum. The residue was resuspended in $1 \% \mathrm{HOAc}-\mathrm{CHCl} 3$ solution to $25 \mathrm{ml}$, and determined according to Yingfan et al. (2004), through an optimized HPLC on a C18 column $(4 \times 6 \mathrm{~mm} \times$ $250 \mathrm{~mm}, 5 \mathrm{~mm}$ particle) with methanol- $0.5 \%$ acetic acid aqueous solution, 90: 10 $(\mathrm{v} / \mathrm{v})$, as mobile phase, at a flow rate of $0.8 \mathrm{ml} / \mathrm{min}$ and $\mathrm{UV}$ detection at $254 \mathrm{~nm}$.

\section{Statistical analysis}

Data obtained were statistically analyzed by using CoStat statistical program software, 1990 and Duncan's multiple range test (Duncan, 1955) was applied at 5\% probability level to compare the differences among time means.

Egypt. J. Rad. Sci. Applic., Vol. 24, No. 1 (2011) 


\section{Results and Discussion}

\section{Effect of gamma irradiation doses on cotton seed fatty acids}

The untreated cotton seed samples contain saturated fatty acids (35\%) with palmetic acid (16:0) as the major one (27\%), while lauric (C 12:0), myristic (C 14:0), stearic (C 18:0) and arachidic (C 20:0) were found as a minor constituents. On the other hand, unsaturated fatty acids found to represent the main constituents (63\%), where linoleic (C 18:2) and oleic (C 18:1) were the major constituents with a percentage of 40.29 and $21.98 \%$, respectively (Table $1 \&$ Fig. 1).

Exposure of cotton seeds to $\gamma$-irradiation with doses of $0.5,1.0$ and 1.5 kGy resulted in some modification of their fatty acid pattern. With respect to saturated fatty acids palmetic acid (16:0) content showed significant increase compared to un-irradiated cotton seeds, palmitic acid (C 16:0) percentage was increased in cotton seed lipids exposed to gamma doses of $0.5,1.0$ and $1.5 \mathrm{kGy}$ with a value of $32.48,30.61$ and $30.52 \%$, respectively compared with the control value (27.11\%) (Table $1 \&$ Fig. 1). Lauric (C 12:0) and stearic acid (C 18:0) contents showed slight increase. lauric (C 12:0) was $1.042 \%$ in untreated sample and increased to $1.154,1.138$ and $1.106 \%$ when the cotton seeds were exposed to gamma irradiation doses of $0.5,1.0$ and $1.5 \mathrm{kGy}$ respectively, while stearic acid (C 18:0) was $2.542 \%$ for the control and had slightly increased to 2.97, 2.79 and $3.214 \%$ when the cotton seeds exposed to doses of $0.5,1.0$ and $1.5 \mathrm{kGy}$, respectively. On the other hand, myristic (C 14:0) and arachidic (C 20:0) acids showed a slight decrease in their percentage in the irradiated samples compared to the control un-irradiated one.

Myristic (C 14:0) content was 3.105\% in untreated cotton seeds, while decreased to $0.865,0.898$ and $0.899 \%$ when the cotton seeds treated by gamma doses of 0.5, 1.0 and $1.5 \mathrm{kGy}$, while, arachidic acid (C 20:0) was decreased from $0.9087 \%$ to $0.5427,0.5153$ and $0.5937 \%$ when the cotton seeds exposed to $\gamma$-irradiation doses of $0.5,1.0$ and $1.5 \mathrm{kGy}$, respectively (Table 1). Dowd et al. (2010) revealed that cotton seed oil contains palmitic and stearic in large amounts are more stable and they are naturally hydrogenated for purposes of keeping. Thus, gamma irradiation doses increase the oil preserving than untreated one.

The unsaturated fatty acids of palmitoleic (C 16:1) and oleic (C 18:1) were increased when the cotton seeds exposed to gamma doses as in (Table $2 \&$ Fig. 1). The palmitoleic acid was $1.509,1.612$ and $1.654 \%$ if cotton seeds treated by gamma doses of $0.5,1.0$ and $1.5 \mathrm{kGy}$, respectively, compared with the control

Egypt. J. Rad. Sci. Applic., Vol. 24, No. 1 (2011) 
value (0.6547), while, oleic acid (C 18:1) percentage was increased from $21.98 \%$ to be $26.31,26.37$ and $27.94 \%$ at $\gamma$-doses of $0.5,1.0$ and $1.5 \mathrm{kGy}$, respectively. It is remarkable that the major constituent linoleic acid (C 18:2) decreased from $40.29 \%$ to be $33.59,36.09$ and $32.57 \%$ at gamma doses of 0.5 , 1.0 and $1.5 \mathrm{kGy}$ respectively (Table 2 \& Fig. 1). This agrees with Rahimi and Bahrani (2011) who stated that linoleic acid content decreased by increasing irradiation doses. The oleic and linoleic content ratio agreed with the fact that there is a negative correlation between linoleic and oleic acid, that is, with increase in olic acid content the linoleic acid content decreases and vice virsa. This is expected since oleic acid is the precursor fatty acid for linoleic acid (Miquel and Browse, 1994, Ohlrogge and Browse, 1995, Shabnam et al., 2011 and Topfer et al., 1995). Cotton seed oil consists of 63\% unsaturated fatty acids, including $22 \%$ mono-unsaturated (oleic) and $40 \%$ poly-unsaturated (linoleic), and $34 \%$ saturated fatty acids with $27 \%$ palmitic, can be described as naturally hydrogenated which make the oil stable for frying without the need for additional processing or the formation of trans fatty acids (Sekhar and Bhaskara, 2011). Moreover, Dowd et al. (2010) showed that the high content of linoleic (C 18:2) in cotton seed lower the oxidative stability than other vegetable oils and make the odour and flavour. In addition, the quality of cotton seed oil had not been seriously affected by either time or temperature of storage during the 2 year period.

TABLE 1. Effect of gamma irradiation doses on the cotton seed saturated fatty acids.

\begin{tabular}{|c|c|c|c|c|}
\hline \multirow{2}{*}{ Fatty acid } & Non-irradiated \% & \multicolumn{3}{|c|}{ Radiated \% } \\
\cline { 2 - 5 } & Control & $\mathbf{0 . 5} \mathrm{kGy}$ & $\mathbf{1} \mathrm{kGy}$ & $\mathbf{1 . 5}^{\mathbf{k G y}}$ \\
\hline \multirow{2}{*}{ Lauric C 12:0 } & $1.042^{\mathbf{a}}$ & $\begin{array}{c}1.154^{\mathbf{a}} \\
\pm 0.008\end{array}$ & $\begin{array}{c}1.138^{\mathbf{a}} \\
\pm 0.0213\end{array}$ & $\begin{array}{c}1.106^{\mathbf{a}} \\
\pm 0.003\end{array}$ \\
\hline \multirow{2}{*}{ Myristic C 14:0 } & $3.105^{\mathbf{a}}$ & $0.865^{\mathbf{c}}$ & $0.898^{\mathbf{c}}$ & $0.899^{\mathbf{b}}$ \\
& \pm 0.055 & \pm 0.004 & \pm 0.013 & \pm 0.012 \\
\hline \multirow{2}{*}{ Palmitic C 16:0 } & $27.11^{\mathbf{d}}$ & $32.48^{\mathbf{a}}$ & $30.61^{\mathbf{c}}$ & $30.52^{\mathbf{b}}$ \\
& \pm 0.068 & \pm 0.049 & \pm 0.076 & \pm 0.024 \\
\hline \multirow{2}{*}{ Stearic C 18:0 } & $2.542^{\mathbf{d}}$ & $2.97^{\mathbf{b}}$ & $2.79^{\mathbf{c}}$ & $3.214^{\mathbf{a}}$ \\
& \pm 0.016 & \pm 0.034 & \pm 0.007 & \pm 0.014 \\
\hline \multirow{2}{*}{ Arachidic C 20:0 } & $0.9087^{\mathbf{a}}$ & $0.5427^{\mathbf{c}}$ & $0.5153^{\mathbf{c}}$ & $0.5937^{\mathbf{b}}$ \\
& \pm 0.013 & \pm 0.010 & \pm 0.003 & 0.003 \\
\hline Ts & 34.707 & 35.0417 & 31.0613 & 33.4147 \\
\hline
\end{tabular}

Ts: Total saturated fatty acids. Each value is the mean of three values \pm Standard Error.

Many workers evaluated gamma radiation doses effects on some crop fatty acids, i.e Mexis and Kontominas (2009) evaluated cashew nuts' quality as a function of gamma irradiation dose in order to determine dose levels causing Egypt. J. Rad. Sci. Applic., Vol. 24, No. 1 (2011) 
minimal undesirable changes to the product of cashew nuts at doses up to $7 \mathrm{kGy}$. Results showed fatty acids determined, stearic acid concentration increased; while, oleic acid decreased with irradiation dose. The irradiation indicating enhanced lipid oxidation.

TABLE 1. Effect of $\gamma$ - irradiation doses on the cotton seed unsaturated fatty acids.

\begin{tabular}{|l|c|c|c|c|}
\hline \multirow{2}{*}{ Fatty acid } & Non-irradiated \% & \multicolumn{3}{|c|}{ Radiated \% } \\
\cline { 2 - 5 } & Control & $\mathbf{0 . 5} \mathrm{kGy}$ & $\mathbf{1} \mathrm{kGy}$ & $\mathbf{1 . 5}^{\mathrm{kGy}}$ \\
\hline \multirow{2}{*}{ Palmitoleic C 16:1 } & $0.6547^{\mathbf{d}}$ & $1.509^{\mathbf{c}}$ & $1.612^{\mathbf{b}}$ & $1.654^{\mathbf{a}}$ \\
& \pm 0.004 & \pm 0.006 & \pm 0.005 & \pm 0.003 \\
\hline \multirow{2}{*}{ Oleic C 18:1 } & $21.98^{\mathbf{d}}$ & $26.31^{\mathbf{b}}$ & $26.37^{\mathbf{c}}$ & $27.94^{\mathbf{a}}$ \\
& \pm 0.058 & \pm 0.036 & \pm 0.031 & \pm 0.023 \\
\hline \multirow{2}{*}{ Linoleic C 18:2 } & $40.29^{\mathbf{a}}$ & $33.59^{\mathbf{c}}$ & $36.09^{\mathbf{b}}$ & $32.57^{\mathbf{d}}$ \\
& \pm 0.049 & \pm 0.065 & \pm 0.086 & \pm 0.035 \\
\hline Tu & 62.9247 & 61.409 & 62.382 & 62.164 \\
\hline
\end{tabular}

Tu: Total unsaturated fatty acids. Each value is the mean of three values \pm Standard Error.

Fig. 1. Chromatogram of saturated and unsaturated fatty acids as affected by gamma irradiation doses.
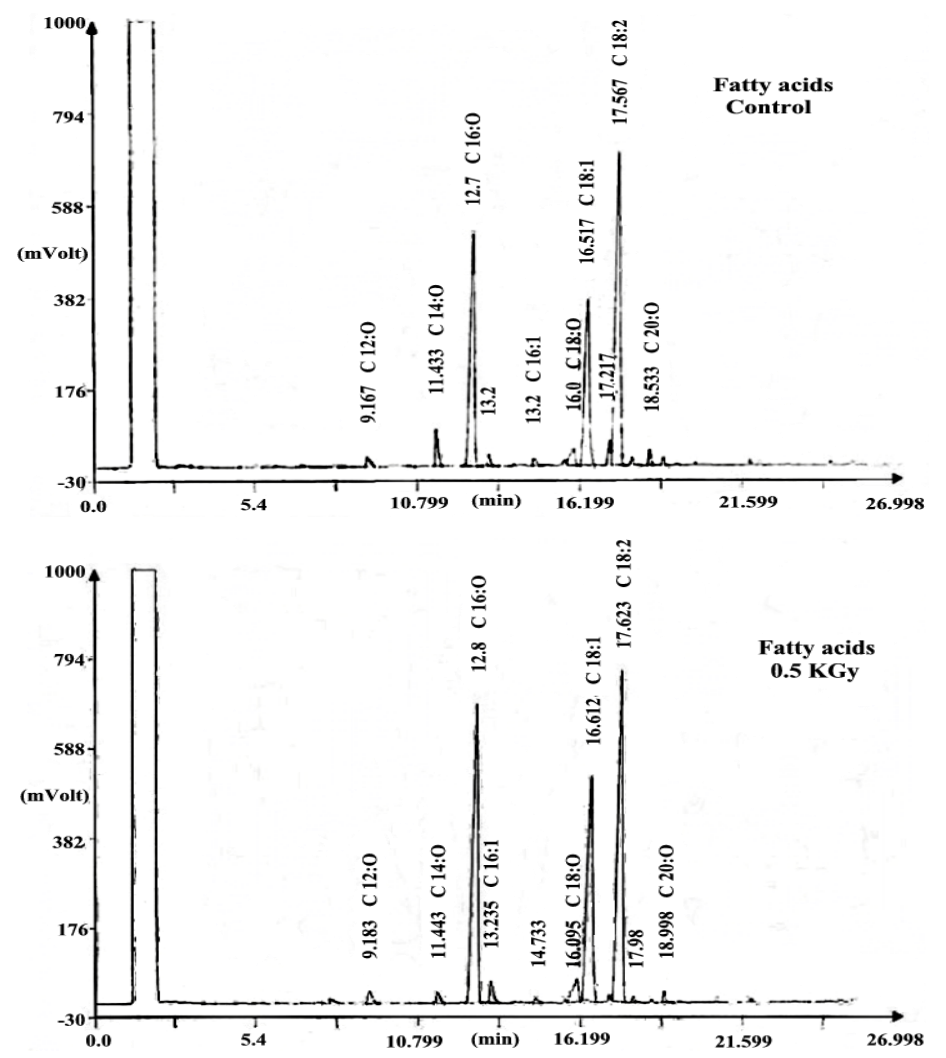

Egypt. J. Rad. Sci. Applic., Vol. 24, No. 1 (2011) 

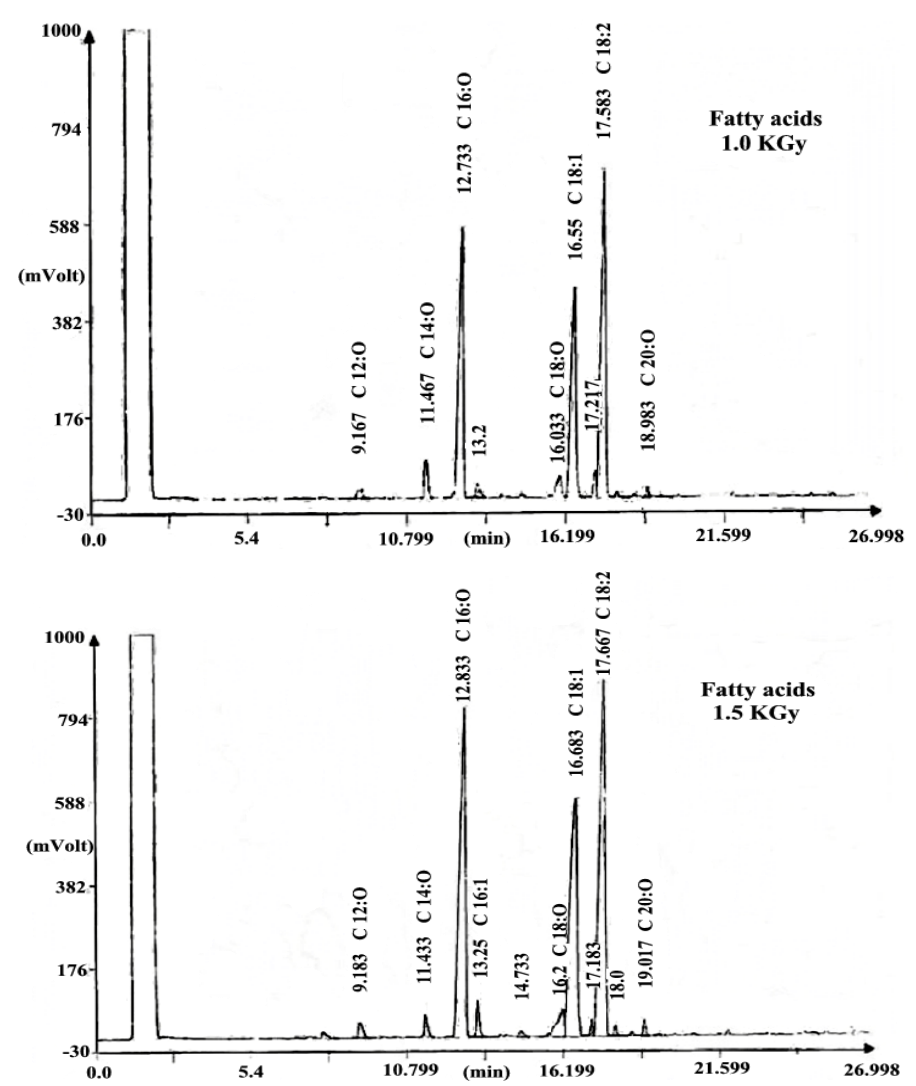

\section{Effect of gamma irradiation doses on gossypol bound oil}

The percent of gossypol in non-irradiated oil was $0.00357 \%$ (Table $3 \&$ Fig. 2), but it increased slightly too; $0.00926,0.01058$ and $0.01114 \%$ when the oil irradiated as cotton seeds by $\gamma$-irradiation doses of $0.5,1.0$ and $1.5 \mathrm{kGy}$, respectively. Although gamma irradiation doses increase the gossypol bound oil, the increasing amount is not harmful to the human body as showed by (Hron et al., 1987) who stated that some amount of gossypol tends to react with many natural substances in cotton seed and forms the bound gossypol that is non-harmful. However the unreacted gossypol known as "free gossypol" is toxic.

Gossypol still has toxins that decrease spermatogenesis and sperm motility in men. This is a topic that should be brought up with fertility doctors because cotton seed oil is a very commonly used ingredient in many foods Savanam and Bhaskara (2011).

Egypt. J. Rad. Sci. Applic., Vol. 24, No. 1 (2011) 


\section{Effect of gamma irradiation doses on $\beta$-sitosterol bound oil.}

$\beta$-sitosterol content in cotton seed oil $0.1177 \%$ was found to increase by exposure to $\gamma$-irradiation. Although it increases in the three irradiation doses, 0.5 $\mathrm{kGy}$ is considered the best irradiation doses with a value of $0.1341 \%$ (Table $3 \&$ Fig. 3). So, gamma irradiation doses especially dose of $0.5 \mathrm{kGy}$ increase $\beta$-sitosterol in oil irradiated as cotton seeds. It increase the healthy valuable of oil because, $\beta$-sitosterol is known to control cholesterol levels, reduce the activity of cancer cell, promote prostate gland health and enhance immunity in the human body (Ye et al., 2010).

TABLE 3. Effect of gamma irradiation doses on the gossypol and $\beta$-sitosterol bounds oil in the cotton seeds.

\begin{tabular}{|c|c|c|c|c|}
\hline $\begin{array}{c}\text { Gamma doses } \\
(\mathrm{kGy})\end{array}$ & $\begin{array}{c}\text { Gossypol } \\
(\mathrm{mg} / 100 \mathrm{~g} \text { oil })\end{array}$ & $\begin{array}{c}\text { Gossypol } \\
\%\end{array}$ & $\begin{array}{c}\boldsymbol{\beta} \text {-sitosterol } \\
(\mathrm{mg} / 100 \mathrm{~g} \text { oil })\end{array}$ & $\begin{array}{c}\boldsymbol{\beta} \text {-sitosterol } \\
\%\end{array}$ \\
\hline Control & $\begin{array}{c}3.57^{\mathbf{a}} \\
\pm 0.032\end{array}$ & 0.00357 & $\begin{array}{c}117.7^{\mathbf{d}} \\
\pm 0.154\end{array}$ & 0.1177 \\
\hline $\mathbf{0 . 5}$ & $\begin{array}{c}9.26^{\mathbf{a}} \\
\pm 0.040\end{array}$ & 0.00926 & $\begin{array}{c}134.1^{\mathbf{a}} \\
\pm 0.124\end{array}$ & 0.1341 \\
\hline $\mathbf{1}$ & $\begin{array}{c}10.58^{\mathbf{a}} \\
\pm 0.046\end{array}$ & 0.01058 & $\begin{array}{c}128.8^{\mathbf{b}} \\
\pm 0.119\end{array}$ & 0.1288 \\
\hline $\mathbf{1 . 5}$ & $\begin{array}{c}11.14^{\mathbf{a}} \\
\pm 0.035\end{array}$ & 0.01114 & $\begin{array}{c}126.7^{\mathbf{c}} \\
\pm 0.115\end{array}$ & 0.1267 \\
\hline
\end{tabular}

Each value is the mean of three values \pm Standard Error.

Fig. 2. Chromatogram of gossypol bound oil as affected by $\boldsymbol{\gamma}$-irradiation doses.

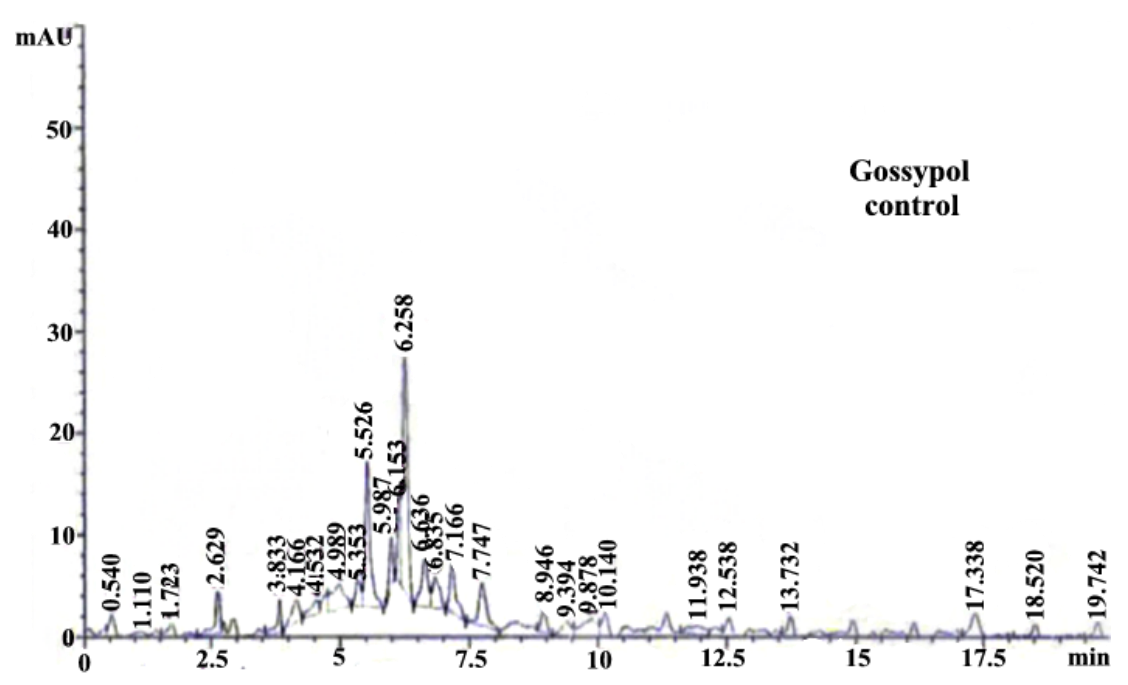

Egypt. J. Rad. Sci. Applic., Vol. 24, No. 1 (2011) 

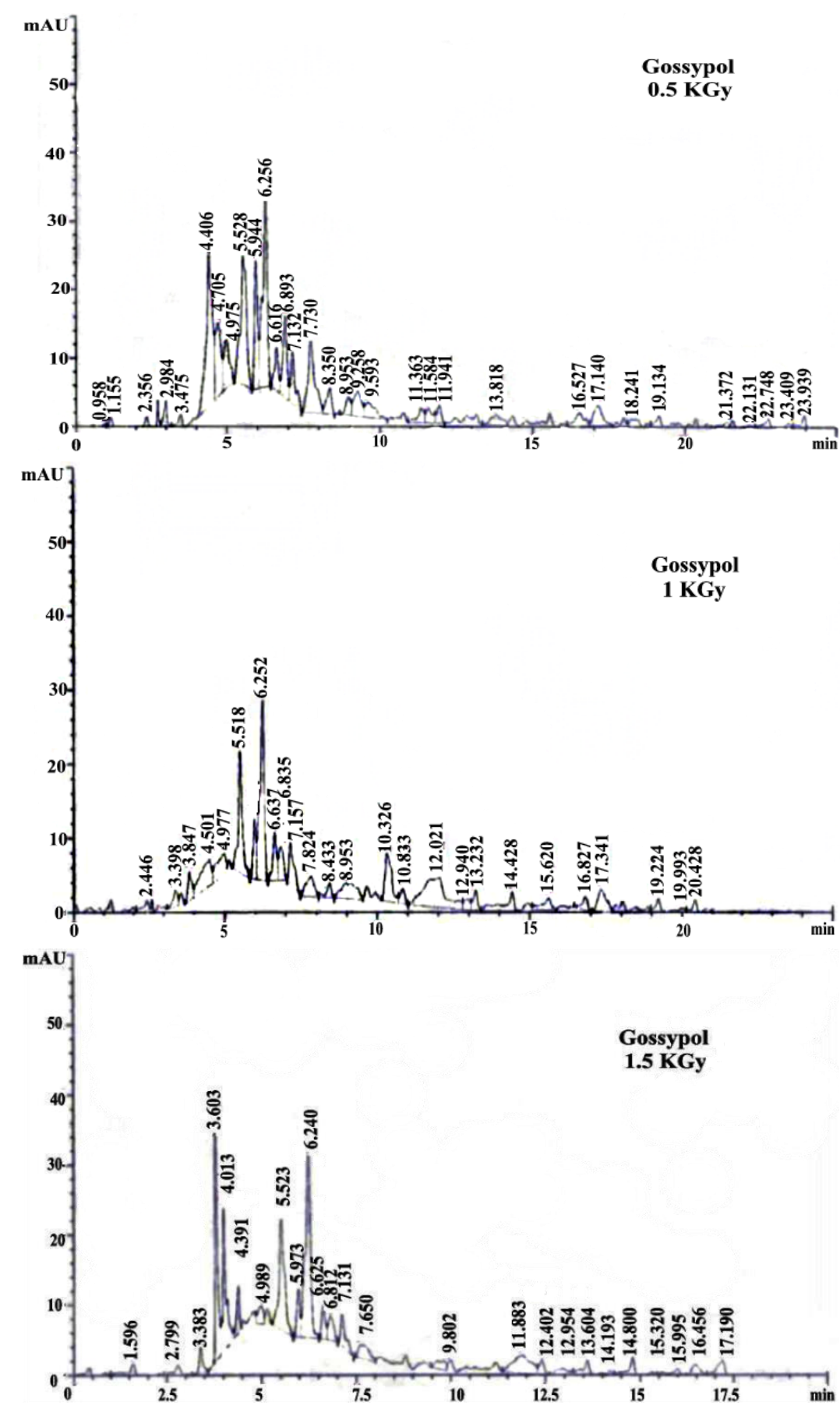

Egypt. J. Rad. Sci. Applic., Vol. 24, No. 1 (2011) 
Generally, gamma irradiation dose of $0.5 \mathrm{kGy}$ is considered the best dose enhance some oil chemical characteristics when irradiated as cotton seeds i.e. fatty acids of lauric, palmitic, palmitoleic, stearic, oleic that were naturally hydrogenated for long time preserve and antioxidants oil for long frying period. In addition, the same dose increase $\beta$-sitosterol content which improve the oil healthy and quality properties.

Fig. 3. Chromatogram of $\beta$-sitosterol bound oil as affected by $\gamma$-irradiation doses.
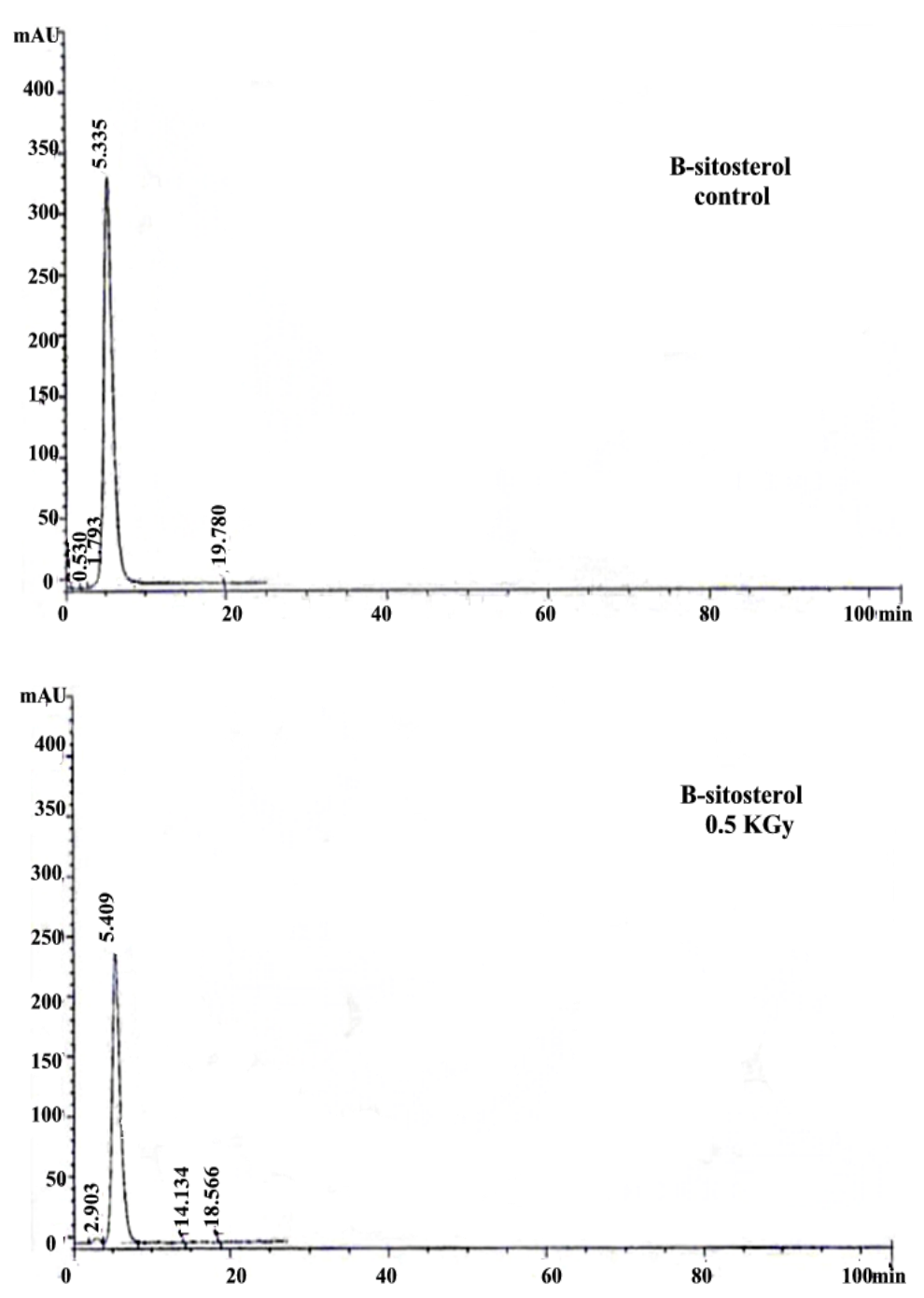

Egypt. J. Rad. Sci. Applic., Vol. 24, No. 1 (2011) 


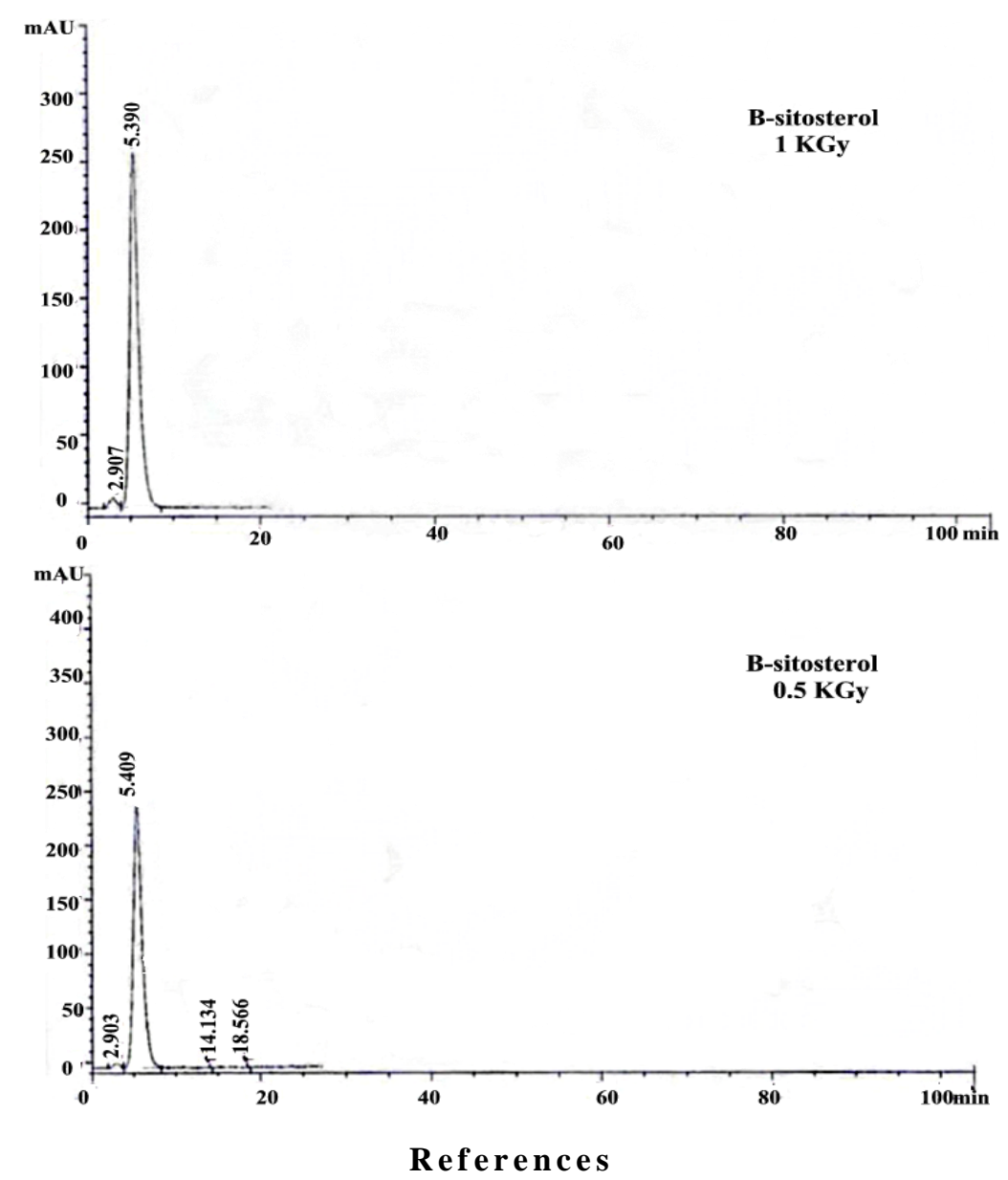

A.O.A.C. (2000) Official methods of analysis of the Association of Official Analytical Chemist. $14^{\text {th }} \mathrm{cd}$ Washington, D.C.

Abd EI-Aziz, A. B. and Abd EI-Khalek, H. H. (2011) Antimicrobial proteins and oil seeds from pumpkin (Cucurbita moschata). Nature \& Sci., 9, 105.

Awad, A. B. and Fink, C. S. (2000) Phytosterols as anticancer dietary components: evidence and mechanism of Action 1, 2. J. Nutr., 130, 2127.

Bouic, P., Etsebeth, S., Liebenberg, R., Albrecht, C., Pegel, K. and Van Jaarsveld, P. (1996) Beta-sitosterol and Beta-sitosterol glucoside stimulate human peripheral blood lymphocyte proliferation: Implications for their use as an immunomodulatory vitamin combination. Int. J. Immunopharmac., 18, 693.

Chen, R. (1991) Plant oil. Biomedicine, Taipei Publishers, Taiwan. p. 283.

Egypt. J. Rad. Sci. Applic., Vol. 24, No. 1 (2011) 
CoStat Software (1990) Microcomputer program analysis. V. 4.2, CoHort Sofware, Berkeley, $C A$.

Dowd, M., Boykin, D., Meredith, W., Campbell, B., Bourland, F., Gannaway, J., Glass, K. and Zhang, J. (2010) Fatty acid profiles of cottonseed genotypes from the national cotton variety trials. J. Cotton Sci., 14, 64.

Duncan, D. B. (1955) Multiple ranges and multiple F.test. Biomerics., 11, 1.

Farag, R., Hallabo, S., Hewedi, F. and Basyony, A. (1981) Chemical evaluation of rape seed. Fette Seifen Anstrichmittel., 88, 391.

Hron, R., Koltun, S., Pominski, J. and Abraham, G. (1987) The potential commercial aspects of gossypol. J. Am. Oil Chem. Soc., 64, 1315.

Jodi, S. and Gabriela, R. (2008) Modifying gossypol in cotton (Gossypium hirsutum L.): A cost effective Method for small seed samples. The J. Cotton Sci., 12, 202.

Luna, S., Bento, E., Sant'Ana, A. and Hawkes, G. (2004) H and 13C NMR Experiments and Chemical Shifts Calculations on Gossypol: a Compound Extracted from Cottonseeds. Ann. Magn. Reson., 3, 17.

Mac-Latchy, D., Van, D. and Kraak, G. (1995) The phytoestrogen betasitosterol alters the reproductive endocrine status of goldfish. Toxicol. Appl. Pharmacol., 134, 305.

Mahmoudabad, S. and Roudbaneh, M. (2011) Investigation of electron beam irradiation effects on anti-nutritional factors, chemical composition and digestion kinetics of whole cottonseed, soybean and canola seeds. Radiat. Phys. Chem., 10, 1.

Mexis, S. and Kontominas, M. (2009) Effect of gamma irradiation on the physicochemical and sensory properties of cashew nuts (Anacardium occidentale L.). Food Sci. Technol., 42, 1501.

Miquel, M. and Browse, J. (1994) In Seed Development and Germination (eds Kigel, H. and Galilli, G.), Marcel Dekker, New York, pp. 169-193.

Ohlrogge, J. and Browse, J. (1995) Lipid Biosynthesis. The Plant Cell, 7, 957.

Rahimi, M. and Bahrani, A. (2011) Effect of gamma irradiation on qualitative and quantitative characteristics of canola (Brassica napus L.). Middle-East J. Sci. Res., 8, 519.

Sacks, F. and Katan, M. (2002) Randomized clinical trials on the effects of dietary fat and carbohydrates on plasma lipoproteins and cardiovascular disease. Am. J. Med., 113, 135.

Savanam C. and Bhaskara R. (2011) Cottonseed Oil as Health Oil. Pertanika J. Trop. Agric. Sci. 34, 17.

Sekhar, S. C. and Bhaskara, R. V. K. (2011) Cottonseed Oil as Health Oil. Pertanika J. Trop. Agric. Sci., 34, 17.

Shabnam, A., Jaimini, D., Sarkar, C., Phulara, R. and Pawar, S. (2011) Evaluation of gamma rays-induced changes in oil yield and oleic acid content of niger, Guizotia abyssinica (L. f.) Cass. Curr. Sci., 101, 490.

Egypt. J. Rad. Sci. Applic., Vol. 24, No. 1 (2011) 
Sharma, S., Kumar, M., Goyal, R., Manivannan, B. and Lohiya, N. (1999) Reversible antispermatogenic effect of gossypol in langur monkeys (Presbytis entellus). Adv. Contraception, 15, 15.

Srinivasan, C. S. (2004) Plant variety protection in developing countries: A view from the private seed industry in India. J. New Seeds, 6, 67.

Tatu, A., Miettinen, A. and Helena, G. (2002) Ineffective decrease of serum cholesterol by simvastatin in a subgroup of hypercholesterolemic coronary patients. Atheroscl., 164, 147.

Topfer, R., Martini, N. and Schell, J. (1995) Modification of plant lipid synthesis. J. Science, 268, 681.

Vogel, A. J. (1975) A text book of practical organic chemistry. English Language Book Society and Longman Group Ltd. London. $3^{\text {rd }}$ ed. P. 969.

Wang, M., Wang, J. S. and Li, B. L. (1985) Determination of Gossypol with high performance liquid chromatography; Acta Phama. Sinica, 20, 682.

Wang, X., Wang, S., Wong, L, Chow, J., Nicholls, Y., Wong, Y., Liu, D., Kwong, J., Sham, G. and Tsa, S. (2000) Cytotoxic effect of gossypol on colon carcinoma cells. Life Sci., 67, 2663.

Wi, S., Chung, B., Kim, J., Baek, M., Yang, D., Lee, J. and Kim, J. (2005) Ultrastructural changes of cell organelles in Arabidopsis stem after gamma irradiation. J. Plant Biol., 48, 195.

Ye, J., Chang, W., Yuan Hsieh, D. and Hsiao, M. (2010) Extraction and analysis of $\beta$ sitosterol in herbal Medicines. J. Med. Plants Res., 4, 522.

Yi, S. and Xiao, B. C. (2009) Isolation and identification of an isomer of $\beta$-sitosterol by HPLC and GC-MS. Health., 1, 203.

Yingfan, C., Hong, Z., Yu, Z., Jianchuan, M., Jimku, B., Chen, M., Fang, Y., Jie, B. and Fang, C. (2004) An optimized gossypol high performance liquid chromatography assay and its application in evaluation of different gland genotypes of cotton. J. Biosci., 29, 101.

Zak, A., Vecka, M., Tvrzicka, E., Hruby, M., Novak, F., Papezova, H., Lubanda, H., Vesela, L. and Stankova, B. (2005) Composition of Plasma Fatty Acids and Non-Cholesterol Sterols in Anorexia Nervosa. Physiol. Res., 54, 443.

Zock, P., de Vries, J. and Katan, M. (1994) Impact of myristic acid versus palmitic acid on serum lipid and lipoprotein levels in healthy women and men. Arterioscler. Thromb. Vasc. Biol., 14, 567. 


$$
\begin{aligned}
& \text { تأثير جرعات أشعة جامـا على بعض الصفات الكيميائية لزيت }
\end{aligned}
$$

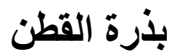

$$
\begin{aligned}
& \text { عمر إبراهيم صالح } \\
& \text { قسم بحوث المنتجات الطبيعية ، المركز القومى لبحوث وتكنولوجيا الإشعاع ، }
\end{aligned}
$$

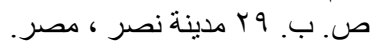

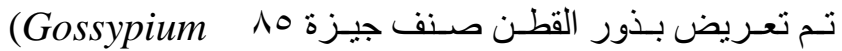

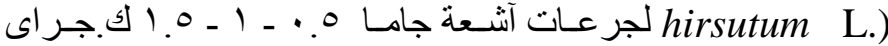

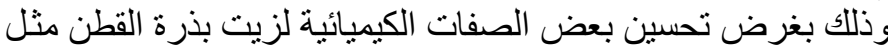

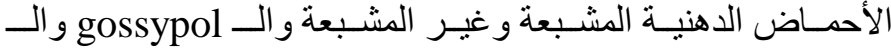

涫

وقد أشارت النتائج إلى ما يلى بلى:

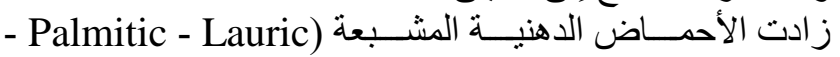

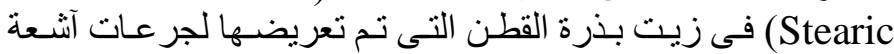

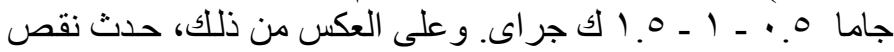

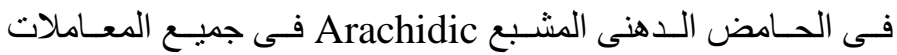

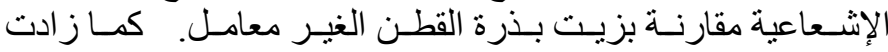

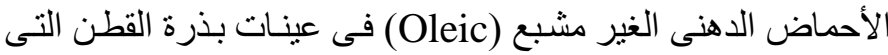

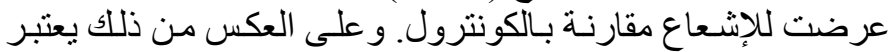

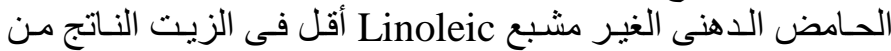

البذور المعرضة للإشعاع عن البذور الغير معاملة.

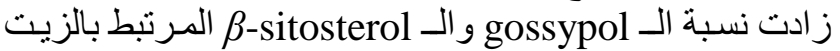

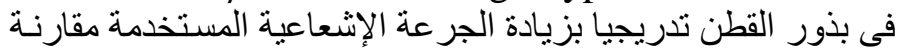

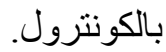

Egypt. J. Rad. Sci. Applic., Vol. 24, No. 1 (2011) 